REVIEW ARTICLE

\title{
Variation in Selected Chemical Element Contents Associated with Malignant Tumors of Human Thyroid Gland
}

\author{
Vladimir Zaichick $^{1 *}$ and Sofia Zaichick ${ }^{2}$ \\ ${ }^{1}$ Radionuclide Diagnostics Department, Medical Radiological Research Centre, Russia \\ ${ }^{2}$ Laboratory of Dr. Gabriela Caraveo Piso, Feinberg School of Medicine, Northwestern University, \\ USA
}

\begin{abstract}
Thyroid cancer is an internationally important health problem. The aim of this exploratory study was to evaluate whether significant changes in the thyroid tissue levels of $\mathrm{Br}, \mathrm{Ca}, \mathrm{Cl}, \mathrm{I}$, $\mathrm{K}, \mathrm{Mg}, \mathrm{Mn}$, and $\mathrm{Na}$ exist in the malignantly transformed thyroid. Thyroid tissue levels of eight chemical elements were prospectively evaluated in 41 patients with thyroid malignant tumors and 105 healthy inhabitants. Measurements were performed using non-destructive instrumental neutron activation analysis with high resolution spectrometry of short-lived radionuclides. Tissue samples were divided into two portions. One was used for morphological study while the other was intended for chemical element analysis. It was found that contents of $\mathrm{Br}, \mathrm{Cl}, \mathrm{K}, \mathrm{Mg}$, and $\mathrm{Na}$ were significantly higher and content of I was drastically lower in cancerous tissues than in normal tissues. Thus, the study showed that the malignant transformation was accompanied by considerable changes in chemical element contents of thyroid parenchyma.
\end{abstract}

\section{Keywords}

Thyroid malignant tumors, intact thyroid, chemical elements, instrumental neutron activation analysis

6 Open Access

Citation: Zaichick V., Zaichick S. Variation in Selected Chemical Element Contents Associated with Malignant Tumors of Human Thyroid Gland. Cancer Studies. 2018; 2(1):2.

Received: January 02,2018

Accepted: March 23, 2018

Published: April 06, 2018

Copyright: (๑) 2018 Zaichick V. This is an open access article distributed under the terms of the Creative Commons Attribution License, which permits unrestricted use, distribution, and reproduction in any medium, provided the original author and source are credited.

\section{Corresponding author:}

Vladimir Zaichick, Radionuclide Diagnostics Department, Medical Radiological Research Centre, Russia.

E-mail: vezai@obninsk.com

\section{Introduction}

Thyroid cancer (TC) is the most common endocrine malignancy. TC incidence has dramatically increased in the recent decades. ${ }^{1}$ During the same period no other cancer has increased as much as TC. With the worldwide increase in the incidence of TC, it has become the fifth most common cancer in women..$^{2-4}$ In some countries, the incidence of TC has increased extremely fast, and it has been the most common cancer for the last years. ${ }^{5}$

Although the etiology of TC is unknown, several risk factors including deficiency or excess of such micronutrient as iodine (I) have been well identified. ${ }^{6-17}$ It was also reported that incidence of TC and mortality from this disease increases progressively with advancing age ${ }^{18,19}$ For example, a 37 -fold increase in hazard ratio from age $<40$ years to age $>70$ years was showed in the study of 3664 TC patients that received surgery and adjuvant treatment at Memorial Sloan Kettering Cancer Center from the years 1985 to $2010 .^{19}$

Besides I involved in thyroid function, other chemical elements have also essential physiological functions such as maintenance and regulation of cell function, gene regulation, activation or inhibition of enzymatic reactions, and regulation of membrane function. Essential or toxic (mutagenic, carcinogenic) properties of chemical elements depend on tissue-specific need or tolerance, respectively. ${ }^{20}$ Excessive accumulation or an imbalance of the chemical elements may disturb the cell functions and may result in cellular degeneration, death or malignant transformation. ${ }^{20-22}$

In our previous study a significant positive correlation between age and some chemical element contents in the thyroid was observed. ${ }^{23-28}$ For example, a strongly pronounced 
tendency of age-related increase in bromine $(\mathrm{Br})$, calcium $(\mathrm{Ca})$, and I mass fractions was demonstrated by using non-destructive instrumental neutron activation analysis with high resolution spectrometry of short-lived radionuclides (INAA-SLR). ${ }^{23,27}$ In addition, a significant positive correlation was seen between the contents of I and sodium $(\mathrm{Na})$ in female thyroid, ${ }^{23}$ and also between I and $\mathrm{Ca}$ in male thyroid. ${ }^{27}$ It was concluded that high intra-thyroidal I and $\mathrm{Ca}$ concentrations are probably one of the main factors acting in both initiation and promotion stages of thyroid carcinogenesis, ${ }^{23,27}$ as it was earlier shown by us for $\mathrm{Ca}$ and some other chemical elements in prostate gland. ${ }^{29-35}$ Moreover, it seems fair to suppose that besides I and $\mathrm{Ca}$, such chemical elements as $\mathrm{Br}$, chlorine $(\mathrm{Cl})$, potassium $(\mathrm{K})$, magnesium $(\mathrm{Mn})$, manganese $(\mathrm{Mn})$, and sodium $(\mathrm{Na})$ also play arolein the pathophysiology of the thyroid.

The aim of this work was to assess the $\mathrm{Br}, \mathrm{Ca}, \mathrm{Cl}, \mathrm{I}, \mathrm{K}, \mathrm{Mg}, \mathrm{Mn}$, and $\mathrm{Na}$ contents in TC tissue using INAA-SLR analysis and also to compare the levels of chemical elements in the malignant thyroid with those in intact (normal) gland of apparently healthy persons.

All studies were approved by the Ethical Committees of the Medical Radiological Research Centre, Obninsk. All procedures performed in studies involving human participants were in accordance with the ethical standards of the institutional and/or national research committee and with the 1964 Helsinki declaration and its later amendments or comparable ethical standards.

\section{Material and Methods}

All patients suffered from TC ( $n=41$, mean age $M \pm S D$ was $46 \pm 15$ years, range $16-75)$ were hospitalized in the Head and Neck Department of the Medical Radiological Research Centre. Thick-needle puncture biopsy of suspicious nodules of the thyroid was performed for every patient, to permit morphological study of thyroid tissue at these sites and to estimate their chemical element contents. In all cases the diagnosis has been confirmed by clinical and morphological results obtained during studies of biopsy and resected materials. Histological conclusions for malignant tumors were: 25 papillary adenocarcinomas, 8 follicular adenocarcinomas, 7 solid carcinomas, and 1 reticulosarcoma.

Normal thyroids for the control group samples were removed at necropsy from 105 deceased (mean age $44 \pm 21$ years, range 2-87), who had died suddenly. The majority of deaths were due to trauma. A histological examination in the control group was used to control the age norm conformity, as well as to confirm the absence of micro-nodules and latent cancer.

All tissue samples were divided into two portions using a titanium scalpel. ${ }^{36}$ One was used for morphological study while the other was intended for chemical element analysis. After the samples intended for chemical element analysis were weighed, they were freeze-dried and homogenized. ${ }^{37}$ The pounded samples weighing about 5-10 mg (for biopsy) and $100 \mathrm{mg}$ (for resected materials) was used for chemical element measurement by INAA-SLR. The samples for INAA-SLR were sealed separately in thin polyethylene films washed beforehand with acetone and rectified alcohol. The sealed samples were placed in labeled polyethylene ampoules.

To determine contents of the elements by comparison with a known standard, biological synthetic standards (BSS) prepared from phenol-formaldehyde resins were used. ${ }^{38}$ In addition to BSS, aliquots of commercial, chemically pure compounds were also used as standards. Ten certified reference material (CRM) IAEA H-4 (animal muscle) sub-samples weighing about $100 \mathrm{mg}$ were treated and analyzed in the same conditions as thyroid samples to estimate the precision and accuracy of results.

The content of $\mathrm{Br}, \mathrm{Ca}, \mathrm{Cl}, \mathrm{I}, \mathrm{K}, \mathrm{Mg}, \mathrm{Mn}$, and $\mathrm{Na}$ were determined by INAA-SLR using a horizontal channel equipped with the pneumatic rabbit system of the WWR-c research nuclear reactor (Branch of Karpov Institute, Obninsk). The neutron flux in the channel was 1.7 $\times 10^{13} \mathrm{n} \mathrm{cm}^{-2} \mathrm{~s}^{-1}$. Ampoules with thyroid tissue samples, SSB, intralaboratory-made standards, and certified reference material were put into polyethylene rabbits and then irradiated separately for $180 \mathrm{~s}$. Copper foils were used to assess neutron flux.

The measurement of each sample was made twice, 1 and $120 \mathrm{~min}$ after irradiation. The duration of the first and second measurements was 10 and $20 \mathrm{~min}$, respectively. A coaxial 98$\mathrm{cm}^{3} \mathrm{Ge}(\mathrm{Li})$ detector and a spectrometric unit (NUC 8100), including a PC-coupled multichannel analyzer, were used for measurements. The spectrometric unit provided 2.9$\mathrm{keV}$ resolution at the ${ }^{60} \mathrm{Co} 1,332-\mathrm{keV}$ line. Details of used nuclear reactions, radionuclides, 
and gamma-energies were presented in our earlier publications concerning the INAA-SLR chemical element contents in human thyroid, scalp hair, and prostate..$^{7,39-41}$

A dedicated computer program for INAA mode optimization was used. ${ }^{42}$ All thyroid samples were prepared in duplicate, and mean values of chemical element contents were used in final calculation. Using Microsoft Office Excel, a summary of the statistics, including, arithmetic mean, standard deviation, standard error of mean, minimum and maximum values, median, percentiles with 0.025 and 0.975 levels was calculated for chemical element contents. The difference in the results between two age groups was evaluated by the parametric Student's $t$ test and non-parametric Wilcoxon-Mann-Whitney $U$-test.

\section{Results}

Table 1 depicts our data for eight chemical elements ( $\mathrm{Br}, \mathrm{Ca}, \mathrm{Cl}, \mathrm{I}, \mathrm{K}, \mathrm{Mg}, \mathrm{Mn}$, and $\mathrm{Na}$ ) in ten sub-samples of CRM IAEAH-4 (animal muscle) and the certified values of this material.

Table 1. INAA-SLR data of chemical element contents in the IAEA H-4 (animal muscle) reference material compared to certified values $(\mathrm{mg} / \mathrm{kg}$, dry mass basis)

\begin{tabular}{lcccc}
\hline Element & \multicolumn{3}{c}{ Certified values } & This work results \\
\cline { 2 - 3 } & Mean & $95 \%$ confidence interval & Type & Mean \pm SD \\
\hline $\mathrm{Br}$ & 4.1 & $3.5-4.7$ & $\mathrm{~N}$ & $5.0 \pm 0.9$ \\
$\mathrm{Ca}$ & 188 & $163-213$ & $\mathrm{~N}$ & $238 \pm 59$ \\
$\mathrm{Cl}$ & 1890 & $1810-1970$ & $\mathrm{~N}$ & $1950 \pm 230$ \\
$\mathrm{~K}$ & 0.08 & - & $\mathrm{N}$ & $<1.0$ \\
$\mathrm{~K}$ & 15800 & $15300-16400$ & $\mathrm{C}$ & $16200 \pm 3800$ \\
$\mathrm{Mg}$ & 1050 & $990-1110$ & $\mathrm{C}$ & $1100 \pm 190$ \\
$\mathrm{Mn}$ & 0.52 & $0.48-0.55$ & $\mathrm{C}$ & $0.55 \pm 0.11$ \\
$\mathrm{Na}$ & 2060 & $1930-2180$ & $\mathrm{C}$ & $2190 \pm 140$ \\
\hline
\end{tabular}

Mean - arithmetical mean, SD - standard deviation, C - certified values, $\mathrm{N}$ - non-certified values.

Table 2 presents certain statistical parameters (arithmetic mean, standard deviation, standard error of mean, minimal and maximal values, median, percentiles with 0.025 and 0.975 levels) of the $\mathrm{Br}, \mathrm{Ca}, \mathrm{Cl}, \mathrm{I}, \mathrm{K}, \mathrm{Mg}, \mathrm{Mn}$, and $\mathrm{Na}$ mass fraction in normal and cancerous thyroid tissue. 
Table 2. Some statistical parameters of $\mathrm{Br}, \mathrm{Ca}, \mathrm{Cl}, \mathrm{I}, \mathrm{K}, \mathrm{Mg}, \mathrm{Mn}$, and $\mathrm{Na}$ mass fraction ( $\mathrm{mg} / \mathrm{kg}$, dry mass basis) in normal and cancerous thyroid

\begin{tabular}{|c|c|c|c|c|c|c|c|c|c|}
\hline Tissue & Element & Mean & SD & SEM & Min & Max & Median & P 0.025 & P 0.975 \\
\hline Normal & $\mathrm{Br}$ & 16.3 & 11.6 & 1.3 & 1.90 & 66.9 & 13.6 & 2.57 & 51.0 \\
\hline \multirow[t]{7}{*}{$n=105$} & $\mathrm{Ca}$ & 1692 & 1022 & 109 & 414 & 6230 & 1451 & 460 & 3805 \\
\hline & $\mathrm{Cl}$ & 3400 & 1452 & 174 & 1030 & 6000 & 3470 & 1244 & 5869 \\
\hline & I & 1841 & 1027 & 107 & 114 & 5061 & 1695 & 230 & 4232 \\
\hline & $\mathrm{K}$ & 6071 & 2773 & 306 & 1740 & 14300 & 5477 & 2541 & 13285 \\
\hline & $\mathrm{Mg}$ & 285 & 139 & 16.5 & 66.0 & 930 & 271 & 81.6 & 541 \\
\hline & $\mathrm{Mn}$ & 1.35 & 0.58 & 0.07 & 0.510 & 4.18 & 1.32 & 0.537 & 2.23 \\
\hline & $\mathrm{Na}$ & 6702 & 1764 & 178 & 3050 & 13453 & 6690 & 3855 & 10709 \\
\hline Cancer & $\mathrm{Br}$ & 139 & 203 & 36 & 6.2 & 802 & 50.2 & 7.75 & 802 \\
\hline \multirow[t]{7}{*}{$\mathrm{n}=41$} & $\mathrm{Ca}$ & 2398 & 2368 & 558 & 452 & 8309 & 1302 & 467 & 7428 \\
\hline & $\mathrm{Cl}$ & 7699 & 2900 & 703 & 4214 & 14761 & 7216 & 4240 & 13619 \\
\hline & I & 71.8 & 62.0 & 10 & 2.00 & 261 & 62.1 & 2.93 & 192 \\
\hline & $\mathrm{K}$ & 9655 & 4444 & 970 & 1660 & 19255 & 8746 & 3181 & 19035 \\
\hline & $\mathrm{Mg}$ & 450 & 232 & 51 & 122 & 1033 & 408 & 126 & 931 \\
\hline & $\mathrm{Mn}$ & 1.90 & 1.41 & 0.32 & 0.100 & 5.79 & 1.59 & 0.100 & 5.37 \\
\hline & $\mathrm{Na}$ & 8556 & 2959 & 646 & 4083 & 17284 & 7264 & 4704 & 14543 \\
\hline
\end{tabular}

$\mathrm{M}$ - arithmetic mean, SD - standard deviation, SEM - standard error of mean, Min - minimum value, Max - maximum value, $\mathrm{P} 0.025$ - percentile with 0.025 level, $\mathrm{P} 0.975$ - percentile with 0.975 level.

The comparison of our results with published data for $\mathrm{Br}, \mathrm{Ca}, \mathrm{Cl}, \mathrm{I}, \mathrm{K}, \mathrm{Mg}, \mathrm{Mn}$, and $\mathrm{Na}$ mass fraction in normal and cancerous thyroid ${ }^{43-60}$ is shown in Table 3. 
Table 3.Median, minimum and maximum value of means $\mathrm{Br}, \mathrm{Ca}, \mathrm{Cl}, \mathrm{I}, \mathrm{K}, \mathrm{Mg}, \mathrm{Mn}$, and $\mathrm{Na}$ contents in normal and cancerous thyroid according to data from the literature in comparison with our results ( $\mathrm{mg} / \mathrm{kg}$, dry mass basis)

\begin{tabular}{|c|c|c|c|c|c|}
\hline \multirow[t]{2}{*}{ Tissue } & \multirow[t]{2}{*}{ Element } & \multicolumn{3}{|c|}{ Published data [Reference] } & \multirow{2}{*}{$\begin{array}{c}\text { This work } \\
\text { M } \pm S D\end{array}$} \\
\hline & & $\begin{array}{l}\text { Median } \\
\text { of means } \\
\qquad(n)^{*}\end{array}$ & $\begin{array}{c}\text { Minimum } \\
\text { of means } \\
M \text { or } M \pm S D,(n)^{\star *}\end{array}$ & $\begin{array}{c}\text { Maximum } \\
\text { of means } \\
M \text { or } M \pm S D,(n)^{\star *}\end{array}$ & \\
\hline \multirow[t]{8}{*}{ Normal } & $\mathrm{Br}$ & $18.1(11)$ & $5.12(44)[43]$ & $284 \pm 44(14)[44]$ & $16.3 \pm 11.6$ \\
\hline & $\mathrm{Ca}$ & $1600(17)$ & $840 \pm 240(10)[45]$ & $3800 \pm 320(29)[45]$ & $1692 \pm 1022$ \\
\hline & $\mathrm{Cl}$ & $6800(5)$ & $804 \pm 80(4)[46]$ & $8000(-)[47]$ & $3400 \pm 1452$ \\
\hline & I & $1888(95)$ & $159 \pm 8(23)[48]$ & $5772 \pm 2708(50)[49]$ & $1841 \pm 1027$ \\
\hline & $\mathrm{K}$ & $4400(17)$ & $46.4 \pm 4.8(4)[46]$ & $6090(17)[50]$ & $6071 \pm 2773$ \\
\hline & $\mathrm{Mg}$ & $390(16)$ & $3.5(-)[51]$ & $840 \pm 400(14)[52]$ & $285 \pm 139$ \\
\hline & $\mathrm{Mn}$ & $1.82(36)$ & $0.44 \pm 11(12)[53]$ & $69.2 \pm 7.2(4)[46]$ & $1.35 \pm 0.58$ \\
\hline & $\mathrm{Na}$ & $8000(9)$ & $438(-)[54]$ & $10000 \pm 5000$ (11) [52] & $6702 \pm 1764$ \\
\hline \multirow[t]{8}{*}{ Cancer } & $\mathrm{Br}$ & $15.7(4)$ & $9.6(1)[55]$ & $160 \pm 112(3)[44]$ & $139 \pm 203$ \\
\hline & $\mathrm{Ca}$ & $1572(6)$ & 390 (1) [56] & 3544 (1) [55] & $2398 \pm 2368$ \\
\hline & $\mathrm{Cl}$ & $940(1)$ & $940 \pm 92(4)[46]$ & $940 \pm 92(4)[46]$ & $7699 \pm 2900$ \\
\hline & I & $78.8(12)$ & $<23 \pm 10(8)[57]$ & $800(1)[58]$ & $71.8 \pm 62.0$ \\
\hline & K & $6878(4)$ & $636 \pm 64$ (4) [46] & 7900 (1) [56] & $9655 \pm 4444$ \\
\hline & $\mathrm{Mg}$ & $320(2)$ & $316 \pm 84(45)[59]$ & $544 \pm 272(6)[60]$ & $450 \pm 232$ \\
\hline & $\mathrm{Mn}$ & $1.83(4)$ & $1.6 \pm 0.8(22)[59]$ & $186 \pm 18(4)[46]$ & $1.90 \pm 1.41$ \\
\hline & $\mathrm{Na}$ & - & - & - & $8556 \pm 2959$ \\
\hline
\end{tabular}

$M$-arithmetic mean, SD - standard deviation, $(n)^{*}$ - number of all references, $(n)^{* *}$ - number of samples.

The ratios of means and the difference between mean values of $\mathrm{Br}, \mathrm{Ca}, \mathrm{Cl}, \mathrm{I}, \mathrm{K}, \mathrm{Mg}, \mathrm{Mn}$, and Na mass fractions in normal and cancerous thyroid are presented in Table 4.

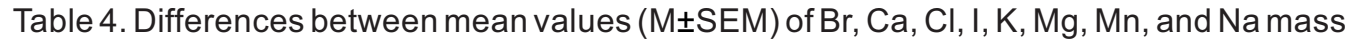
fraction ( $\mathrm{mg} / \mathrm{kg}$, dry mass basis) in normal and cancerous thyroid

\begin{tabular}{lccccc}
\hline Element & \multicolumn{5}{c}{ Thyroid tissue } \\
\cline { 2 - 6 } & Norm & Cancer & Student's -test & U-test & Cancer \\
& $\mathrm{n}=105$ & $\mathrm{n}=41$ & $p \leq$ & $p$ & to Norm \\
\hline $\mathrm{Br}$ & $16.3 \pm 1.3$ & $139 \pm 36$ & $\mathbf{0 . 0 0 1 8}$ & $\leq 0.01$ & 8.53 \\
$\mathrm{Ca}$ & $1692 \pm 109$ & $2398 \pm 558$ & 0.243 & $>0.05$ & 1.42 \\
$\mathrm{Cl}$ & $3400 \pm 174$ & $7699 \pm 703$ & $\mathbf{0 . 0 0 0 0 1 3}$ & $\leq 0.01$ & 2.26 \\
$\mathrm{I}$ & $1841 \pm 107$ & $71.8 \pm 10.0$ & $\mathbf{0 . 0 0 0 0 0 0 0 0 0 0 1}$ & $\leq 0.01$ & 0.039 \\
$\mathrm{~K}$ & $6071 \pm 306$ & $9655 \pm 970$ & $\mathbf{0 . 0 0 1 7}$ & $\leq 0.01$ & 1.59 \\
$\mathrm{Mg}$ & $285 \pm 17$ & $450 \pm 51$ & $\mathbf{0 . 0 0 4 7}$ & $\leq 0.01$ & 1.58 \\
$\mathrm{Mn}$ & $1.35 \pm 0.07$ & $1.90 \pm 0.32$ & 0.107 & $>0.05$ & 1.41 \\
$\mathrm{Na}$ & $6702 \pm 1785$ & $8556 \pm 646$ & $\mathbf{0 . 0 1 1}$ & $\leq 0.01$ & 1.28 \\
\hline
\end{tabular}

$\mathrm{M}$-arithmetic mean, SEM - standard error of mean, statistically significant values are in bold.

\section{Discussion}

\section{Precision and accuracy of results}

Good agreement of the $\mathrm{Br}, \mathrm{Ca}, \mathrm{Cl}, \mathrm{I}, \mathrm{K}, \mathrm{Mg}, \mathrm{Mn}$, and $\mathrm{Na}$ contents analyzed by INAA-SLR with the certified data of CRM IAEA H-4 (Table 1) indicates an acceptable accuracy of the results obtained in the study of chemical elements of the thyroid samples presented in Tables 2-4. 
The mean values and all selected statistical parameters were calculated for eight chemical elements ( $\mathrm{Br}, \mathrm{Ca}, \mathrm{Cl}, \mathrm{I}, \mathrm{K}, \mathrm{Mg}, \mathrm{Mn}$, and $\mathrm{Na}$ ) mass fractions (Table 2). The mass fraction of $\mathrm{Br}$, $\mathrm{Ca}, \mathrm{Cl}, \mathrm{I}, \mathrm{K}, \mathrm{Mg}, \mathrm{Mn}$, and $\mathrm{Na}$ were measured in all, or a major portion of normal and cancerous tissue samples.

\section{Comparison with published data}

Values obtained for $\mathrm{Br}, \mathrm{Ca}, \mathrm{Cl}, \mathrm{I}, \mathrm{K}, \mathrm{Mg}, \mathrm{Mn}$, and $\mathrm{Na}$ contents in the normal human thyroid (Table 3) agree well with median of mean values reported by other researchers. ${ }^{43-54}$ Data cited in Table 3 also include samples obtained from patients who died from different non-endocrine diseases. A number of values for trace element mass fractions were not expressed on a dry mass basis by the authors of the cited references. However, we calculated these values using published data for water $(75 \%)^{61}$ and ash $(4.16 \% \text { on dry mass basis })^{62}$ contents in thyroid of adults.

In cancerous tissues (Table 3 ) our results were comparable with published data for $\mathrm{Ca}, \mathrm{I}, \mathrm{K}$, $\mathrm{Mg}$, and $\mathrm{Mn}$ contents. The obtained mean for $\mathrm{Br}$ was approximately one order of magnitude higher than the median of previously reported means, but within the range of means(Table 3). The obtained mean for $\mathrm{Cl}$ was almost one order of magnitude higher than the only reported result (Table 3). No published data referring $\mathrm{Na}$ contents of cancerous thyroid tissue were found.

The range of means of levels of $\mathrm{Br}, \mathrm{Ca}, \mathrm{Cl}, \mathrm{I}, \mathrm{K}, \mathrm{Mg}, \mathrm{Mn}$, and $\mathrm{Na}$ reported in the literature for normal and for untreated cancerous thyroid vary widely (Table 3 ). This can be explained by a dependence of chemical element content on many factors, including the region of the thyroid, from which the sample was taken, age, gender, ethnicity, mass of the gland, histological types of tumors and the cancer stage. Not all these factors were strictly controlled in cited studies. However, in our opinion, the leading causes of inter-observer variability can be attributed to the accuracy of the analytical techniques, sample preparation methods, and inability of taking uniform samples from the affected tissues. It was insufficient quality control of results in these studies. In many scientific reports, tissue samples were ashed or dried at high temperature for many hours. In other cases, thyroid samples were treated with solvents (distilled water, ethanol, formalin etc.). There is evidence that during ashing, drying and digestion at high temperature some quantities of certain chemical elements are lost as a result of this treatment. That concern not only such volatile halogen as $\mathrm{Br}$, but also other chemical elements investigated in the study. ${ }^{63-65}$

\section{Effect of malignant transformation on chemical element contents}

From Table 4, it is observed that in cancerous tissues the mass fraction of $\mathrm{I}$ is almost 26 times lower whereas mass fractions of $\mathrm{Br}, \mathrm{Cl}, \mathrm{K}, \mathrm{Mg}$, and $\mathrm{Na}$ are approximately 8.5, 2.3, 1.6, 1.6, and 1.3 times, respectively, higher than in normal tissues of the thyroid. Thus, if we accept the chemical element contents in thyroid glands in the control group as a norm, we have to conclude that with a malignant transformation the $\mathrm{Br}, \mathrm{Cl}, \mathrm{I}, \mathrm{K}, \mathrm{Mg}$, and $\mathrm{Na}$ contents in thyroid tissue significantly changed.

\section{Role of chemical elements in malignant transformation of the thyroid}

Characteristically, elevated or reduced levels of chemical elements observed in cancerous tissues are discussed in terms of their potential role in the initiation and promotion of thyroid cancer. In other words, using the low or high levels of the chemical element found in cancerous tissues, researchers try to determine the carcinogenic role of the deficiency or excess of each chemical element in investigated organ. In our opinion, abnormal levels of many chemical elements in tumor could be and cause, and also effect of malignant transformation. From the results of such kind studies, it is not always possible to decide whether the measured decrease or increase in chemical element level in pathologically altered tissue is the reason for alterations or vice versa.

Bromine: This is one of the most abundant and ubiquitous of the recognized chemical elements in the biosphere. Inorganic bromide is the ionic form of bromine which exerts therapeutic as well as toxic effects. An enhanced intake of bromide could interfere with the metabolism of iodine at the whole-body level. In the thyroid gland the biological behavior of bromide is more similar to the biological behavior of iodide. ${ }^{66}$

In our previous studies, we found a significant age-related increase of Br content in human thyroid. ${ }^{23,26-28}$ Therefore, a goitrogenic and, probably, carcinogenic effect of excessive Br levels 
in the thyroid of old females was assumed. On the one hand, elevated levels of $\mathrm{Br}$ in $\mathrm{TC}$ tissues, observed in the present study, supports this conclusion. But, on the other hand, bromide compounds, especially potassium bromide $(\mathrm{KBr})$, sodium bromide $(\mathrm{NaBr})$, and ammoniumbromide $(\mathrm{NH} 4 \mathrm{Br})$, are frequently used as sedatives in Russia. ${ }^{67}$ It may be the reason for elevated levels of $\mathrm{Br}$ in specimens of patients with TC. Nevertheless, the accumulation of $\mathrm{Br}$ in neoplastic thyroid tissues could possibly be explored for diagnosis of TC.

Chlorine: $\mathrm{Cl}$ is a ubiquitous, extracellular electrolyte essential to more than one metabolic pathway. $\mathrm{Cl}$ exists in the form of chloride in the human body. In the body, it is mostly present as sodium chloride. Therefore, as usual, there is a correlation between $\mathrm{Na}$ and $\mathrm{Cl}$ contents in tissues and fluids of human body. It is well known that $\mathrm{Cl}$ mass fractions in samples depend mainly on the extracellular water volume, including the blood volumes, in tissues.68 Cancerous tissues are predominantly highly vascularized lesions. ${ }^{69-75}$ Thus, it is possible to speculate that thyroid malignant tumors are characterized by an increase of the mean value of the $\mathrm{Cl}$ mass fraction because the level of tumor vascularization is higher than that in normal thyroid tissue. Overall, the elevated levels of $\mathrm{Cl}$ in neoplastic thyroids could possibly be explored for diagnosis of TC.

lodine: Compared to other soft tissues, the human thyroid gland has higher levels of I, because this element plays an important role in its normal functions, through the production of thyroid hormones (thyroxin and triiodothyronine) which are essential for cellular oxidation, growth, reproduction, and the activity of the central and autonomic nervous system. Malignant transformation is accompanied by a loss of tissue-specific functional features, which leads to a significant reduction in I content associated with functional characteristics of the human thyroid tissue. Drastically low level of I content in neoplastic thyroids could possibly be explored for diagnosis of TC.

Potassium: An uncontrollable cell proliferation characterize the malignant tumors. Therefore, morphological structures of TC tissue differ from the structure of normal thyroid parenchyma. Because $\mathrm{K}$ is mainly an intracellular electrolyte, an elevated level of $\mathrm{K}$ content in the TC tissue might reflect increase of ratio "mass of transformed thyroid cell - mass of follicular colloid". Nevertheless, the accumulation of K in neoplastic thyroids could possibly be explored for diagnosis of TC.

Magnesium: Mg is abundant in the human body. This element is essential for the functions of more than 300 enzymes(e.g. alkaline phosphatases, ATPases, phosphokinases, the oxidative phosphorylation pathway). It plays a crucial role in many cell functions such as energy metabolism, protein and DNA syntheses, and cytoskeleton activation. Moreover, Mg plays a central role in determining the clinical picture associated with thyroid disease. ${ }^{76}$ Experimental data have shown that high doses of magnesium increase the activity of the thyroid gland. ${ }^{77}$ Magnesium deficiency can influence bioavailability and tissue distribution of selenium which then appears diminished. ${ }^{78}$ From these data, one can conclude that $\mathrm{Mg}$ is involved in the thyroid function. If so, significant reduction in $\mathrm{Mg}$ content cam be associate with TC, because malignant transformation is accompanied by a loss of thyroid-specific functional features. However, it is well known that malignant tumors have a usually higher Mg levels than do normal tissues, ${ }^{79-85}$ possibly caused by the "retention" of Mg by the tumor, ${ }^{86}$ as a result of the high $\mathrm{Mg}$ requirement of growing cells. In addition, cultured proliferating cells have long been known to contain more magnesium than quiescent cells, and experimental conditions that decreased magnesium availability affected cell proliferation rate. ${ }^{87}$ Thus, the elevated levels of $\mathrm{Mg}$ in neoplastic thyroids could possibly be explored for diagnosis of TC.

Sodium: Knowledge concerning ion regulation in many normal and abnormal cell processes has had a rapid development. It was found, among other regulations, that sodium-calcium exchange is associated with the cytoskeleton and the cell membrane. A hypothesis was eventually established that a wide variety of pathological phenomena ranging from acute cell death to chronic processes, such as neoplasia, all have a common series of cellular reactions. ${ }^{88}$ In accordance with this hypothesis, concentrations of sodium were found to be enhanced in human and animal neoplastic tissues. ${ }^{89,90}$ Moreover, the hypothesis that physiological and biochemical changes associated with proliferating malignant tumors may cause an increase in total tissue sodium concentration was tested with non-invasive, quantitative ${ }^{23} \mathrm{Na}$ magnetic resonance imaging in patients with benign and malignant breast tumors. It was shown that elevated $\mathrm{Na}$ concentrations in breast lesions appears to be a 
cellular-level indicator associated with malignancy. ${ }^{91}$ In addition, Na is mainly an extracellular electrolyte and its elevated level in malignant tumors might link with a high tumor vascularization (see Chlorine). Anyway, it seems that the accumulation of $\mathrm{Na}$ is a generic property of malignant tumors.

\section{Limitations}

This study has several limitations. Firstly, analytical techniques employed in this study measure only eight chemical elements $(\mathrm{Br}, \mathrm{Ca}, \mathrm{Cl}, \mathrm{I}, \mathrm{K}, \mathrm{Mg}, \mathrm{Mn}$, and $\mathrm{Na}$ ) mass fractions. Future studies should be directed toward using other analytical methods which will extend the list of chemical elements investigated in normal and cancerous thyroid tissue. Secondly, the sample size of TC group was relatively small and prevented investigations of chemical element contents in TC group using differentials like gender, histological types of tumors, stage of disease, and dietary habits of healthy persons and patients with TC. Lastly, generalization of our results may be limited to Russian population. Despite these limitations, this study provides evidence on cancer-specific tissue $\mathrm{Br}, \mathrm{Cl}, \mathrm{I}, \mathrm{K}, \mathrm{Mg}$, and $\mathrm{Na}$ level alteration and shows the necessity to continue chemical element research of malignant thyroid tumors.

\section{Conclusion}

In this work, chemical elemental analyses were carried out in the tissue samples of normal and cancerous thyroid using INAA-SLR. It was shown that INAA-SLR is an adequate analytical tool for the non-destructive determination of $\mathrm{Br}, \mathrm{Ca}, \mathrm{Cl}, \mathrm{I}, \mathrm{K}, \mathrm{Mg}, \mathrm{Mn}$, and $\mathrm{Na}$ contents in the tissue samples of human thyroid glands, including core needle biopsies. It was observed that in malignant tumors content of I was drastically lower $(p<0.000001)$ and contents of $\mathrm{Br}(\mathrm{p}<0.0018), \mathrm{Cl}(\mathrm{p}<0.000013), \mathrm{K}(\mathrm{p}<0.0017), \mathrm{Mg}(\mathrm{p}<0.0047)$, and $\mathrm{Na}(\mathrm{p}<0.011)$ were significantly higher than in normal tissues. In our opinion, the abnormal decrease in level of $\mathrm{I}$, as well as the increase in levels of $\mathrm{Br}, \mathrm{Cl}, \mathrm{K}, \mathrm{Mg}$, and $\mathrm{Na}$ in cancerous tissue might demonstrate an involvement of these elements in etiology and pathogenesis of malignant thyroid tumors. It was supposed that elevated levels of $\mathrm{Br}, \mathrm{Cl}, \mathrm{K}, \mathrm{Mg}$, and $\mathrm{Na}$, as well as reduced levels of I in thyroid tissues can be used as tumor markers.

\section{Acknowledgements}

The authors are extremely grateful to Profs. B.M. Vtyurin and V.S. Medvedev, Medical Radiological Research Center, Obninsk, as well as to Dr. Yu. Choporov, Head of the Forensic Medicine Department of City Hospital, Obninsk, for supplying thyroid samples.

\section{Funding}

There were no any sources of funding that have supported this work.

\section{Conflict of Interests}

The authors have not declared any conflict of interests.

\section{Authors' Contribution}

Vladimir Zaichick and Sofia Zaichick contributed equally to this work. 


\section{References}

1. Kilfoy BA, Zheng T, Holford TR, et al. International patterns and trends in thyroid cancer incidence, 1973-2002. Cancer Causes Control. 2009; 20: 525-531.

2. Jemal RSA, Xu J, Ward E. Cancer statistics, 2010. Cancer J Clin. 2010; 60(5): 277-300.

3. Pellegriti G, Frasca F, Regalbuto C, Squatrito S, Vigneri R. Worldwide increasing incidence of thyroid cancer: update on epidemiology and risk factors. J Cancer Epidemiol. 2013; 2013:10.

4. Wiltshire JJ,Drake TM,Uttley L,Balasubramanian SP.Systematic review of trends in the incidence rates of thyroid cancer. Thyroid. 2016; 26(11): 1541-1152.

5. Jung $\mathrm{K}$, Won $\mathrm{Y}$, Kong $\mathrm{H}$, et al. Cancer statistics in Korea: incidence, mortality, survival, and prevalence in 2011. CancerRes Treat. 2014; 46(2): 109-123.

6. Zaichick V, Tsyb A, Vtyurin BM. Trace elements and thyroid cancer. Analyst. 1995; 120: 817-821.

7. Zaichick V, Choporov Yu. Determination of the natural level of human intra-thyroid iodine by instrumental neutron activation analysis. J Radioanal Nucl Chem. 1996; 207(1): 153-161.

8. Zaichick V, Zaichick S. Normal human intrathyroidal iodine. Sci Total Environ. 1997; 206(1): 39-56.

9. Zaichick V. lodine excess and thyroid cancer. J Trace Elem Exp Med. 1998; 11(4): 508-509.

10. Zaichick V. In vivo and in vitro application of energy-dispersive XRF in clinical investigations: experience and the future. J Trace Elem Exp Med. 1998; 11(4): 509-510.

11. Zaichick V, Iljina T. Dietary iodine supplementation effect on the rat thyroid $131 \mathrm{I}$ blastomogenic action. In: Anke M, et al., eds. Die Bedentung der Mengen- und Spurenelemente. 18. Arbeitstangung. Jena: Friedrich-Schiller-Universität; 1998: 294-306.

12. Zaichick V, Zaichick S. Energy-dispersive X-ray fluorescence of iodine in thyroid puncture biopsy specimens. J Trace Microprobe Tech. 1999; 17(2): 219-232.

13. Zaichick V. Human intrathyroidal iodine in health and non-thyroidal disease. In: Abdulla M, et al., eds. New aspects of trace element research. London and Tokyo: Smith-Gordon and Nishimura; 1999: 114-119.

14. Zaichick V. Relevance of, and potentiality for in vivo intrathyroidal iodine determination. In Vivo Body Composition Studies. Ann N Y Acad Sci. 2000; 904:630-632.

15. Cho BY, Choi HS, Park YJ, et al.Changes in the clinicopathological characteristics and outcomes of thyroid cancer in Korea over the past four decades. Thyroid. 2013; 23(7): 797-804.

16. Shan Z,Chen L,Lian X,et al. lodine status and prevalence of thyroid disorders after introduction of mandatory universal salt iodization for 16 years in China: A cross-sectional study in 10 cities. Thyroid. 2016; 26(8): 1125-1130.

17. Zimmermann MB, Galetti V. lodine intake as a risk factor for thyroid cancer: a comprehensive review of animal and human studies. Thyroid Res. 2015; 8:8.

18. McNally RJ, Blakey K, James PW, et al. Increasing incidence of thyroid cancer in Great Britain, 1976-2005: age-period-cohort analysis. Eur J Epidemiol. 2012; 27(8): 615-22.

19. Ganly I, Nixon IJ, Wang LY, et al.Survival from differentiated thyroid cancer: What has age got to do with it? Thyroid, 2015; 25(10): 1106-1114.

20. Zaichick V. Medical elementology as a new scientific discipline. J Radioanal Nucl Chem. 2006; 269: 303-309.

21. Beyersmann D, Hartwig A. Carcinogenic metal compounds: recent insight into molecular and cellular mechanisms. Arch Toxicol. 2008; 82(8): 493-512.

22. Martinez-Zamudio R, Ha HC. Environmental epigenetics in metal exposure. Epigenetics. 2011; 6(7): 820-827.

23. Zaichick $\mathrm{V}$, Zaichick S.Age-related changes of $\mathrm{Br}, \mathrm{Ca}, \mathrm{Cl}, \mathrm{I}, \mathrm{K}, \mathrm{Mg}, \mathrm{Mn}$, and $\mathrm{Na}$ contents in intact thyroid of females investigated by neutron activation analysis. Curr Updates Aging. 2017; 1: 5.1

24. Zaichick V, Zaichick S. Age-Related Changes of Ag, Co, Cr, Fe, Hg, Rb, Sb, Sc, Se, and Zn Contents in Intact Thyroid of Males Investigated by Neutron Activation Analysis. Curr Trends Biomedical Eng \&Biosci. 2017; 4(4): 555644. 
25. Zaichick V, Zaichick S.Age-related changes of Ag, Co, Cr, Fe, Hg, Rb, Sb, Sc, Se, and Zn contents in intact thyroid of females investigated by neutron activation analysis. J Gerontol Geriatr Med. 2017; 3: 015

26. Zaichick V, Zaichick S.Age-related changes of some trace element contents in intact thyroid of males investigated by energy dispersive X-ray fluorescent analysis. MOJ Gerontol Ger. 2017; 1(5): 00028.

27. Zaichick $\mathrm{V}$, Zaichick S.Age-related changes of $\mathrm{Br}, \mathrm{Ca}, \mathrm{Cl}, \mathrm{I}, \mathrm{K}, \mathrm{Mg}, \mathrm{Mn}$, and $\mathrm{Na}$ contents in intact thyroid of males investigated by neutron activation analysis. J Aging Age Relat Dis. 2017; 1(1): 1002

28. Zaichick V, Zaichick S.Age-related changes of some trace element contents in intact thyroid of females investigated by energy dispersive X-ray fluorescent analysis. Trends Geriatr Healthc. 2017, 1(1): 31-38.

29. Zaichick V, Zaichick S. Trace element contents in adenocarcinoma of human prostate investigated by energy dispersive X-ray fluorescent analysis. Jadenocarcinoma. 2016; 1(1): 1-7.

30. Zaichick V, Zaichick S. Trace element contents in adenocarcinoma of the human prostate gland investigated byneutron activation analysis. Cancer Res Oncol. 2016; 1(1): 1-10.

31. Zaichick V, Zaichick S. The Comparison between the contents and interrelationships of 17 chemical elements in normal and cancerous prostate gland. J Prostate Cancer. 2016; 1(1): 105

32. Zaichick V, Zaichick S. Prostatic tissue levels of 43 trace elements in patients with prostate adenocarcinoma. Cancer Clin Oncol. 2016; 5(1): 79-94.

33. Zaichick V, Zaichick S. Wynchank S. Intracellular zinc excess as one of the main factors in the etiology of prostate cancer. J Anal Oncol. 2016; 5(3): 124-131.

34. Zaichick V. Differences between 66 chemical element contents in normal and cancerous prostate. $J$ Anal Oncol. 2017; 6(1): 37-56.

35. Zaichick V, Zaichick S, Rossmann M. Intracellular calcium excess as one of the main factors in the etiology of prostate cancer. AIMS Mol Sci. 2016, 3(4), 635-647.

36. Zaichick V, Zaichick S. Instrumental effect on the contamination of biomedical samples in the course of sampling. The J Analytical Chem. 1996; 51(12): 1200-1205.

37. Zaichick V, Zaichick S. A search for losses of chemical elements during freeze-drying of biological materials. J Radioanal Nucl Chem. 1997;218(2): 249-253.

38. Zaichick V. Applications of synthetic reference materials in the medical Radiological Research Centre. Fresenius J Anal Chem. 1995; 352: 219-223.

39. Zaichick S, Zaichick V. The effect of age and gender on 37 chemical element contents in scalp hair of healthy humans. Biol Trace Elem Res. 2010; 134(1): 41-54

40. Zaichick S, Zaichick V. INAA application in the agedynamics assessment of $\mathrm{Br}, \mathrm{Ca}, \mathrm{Cl}, \mathrm{K}, \mathrm{Mg}, \mathrm{Mn}$, and Na content in the normal human prostate. J Radioanal Nucl Chem. 2011; 288(1): 197-202.

41. Zaichick $\mathrm{V}$, Zaichick $\mathrm{S}$. The effect of age on $\mathrm{Br}, \mathrm{Ca}, \mathrm{Cl}, \mathrm{K}, \mathrm{Mg}, \mathrm{Mn}$, and $\mathrm{Na}$ mass fraction in pediatric and young adult prostate glands investigated by neutron activation analysis. App/ Radiat Isot. 2013; 82: $145-151$.

42. Korelo AM, Zaichick V. Software to optimize the multielement INAA of medical and environmental samples. In: Activation Analysis in Environment Protection. Dubna, Russia:Joint Institute for Nuclear Research; 1993:326-332.

43. Zhu H, Wang N, Zhang Y, et al. Element contents in organs and tissues of Chinese adult men. Health Phys. 2010; 98(1): 61-73.

44. Salimi J, Moosavi K, Vatankhah S, Yaghoobi A. Investigation of heavy trace elements in neoplastic and non-neoplastic human thyroid tissue: A study by proton-induced X-ray emissions. Iran J Radiat Res. 2004; 1(4): 211-216.

45. Boulyga SF, Zhuk IV, Lomonosova EM, Kanash NV, Bazhanova NN.Determination of microelements in thyroids of the inhabitants of Belarus by neutron activation analysis using the $\mathrm{k} 0$ method. J Radioanal Nucl Chem. 1997; 222 (1-2): 11-14.

46. Reddy S.B., Charles M.J., Kumar M.R., Reddy B.S., Anjaneyulu Ch., Raju G.J.N., SundareswarB., Vijayan $\mathrm{V}$. Trace elemental analysis of adenoma and carcinoma thyroid by PIXE method. Nucl Instrum Methods Phys Res B: Beam Interactions with Materials and Atoms. 2002; 196(3-4): 333-339. 
47. Woodard HQ, White DR. The composition of body tissues. Brit J Radiol. 1986; 708: 1209-1218.

48. Neimark II, Timoschnikov VM. Development of carcinoma of the thyroid gland in person residing in the focus of goiter endemic. Problemy Endocrinilogii. 1978: 24(3): 28-32.

49. Zabala J, Carrion N, Murillo M, et al. Determination of normal human intrathyroidal iodine in Caracas population. J Trace Elem Med Biol. 2009; 23(1): 9-14.

50. Forssen A. Inorganic elements in the human body. Ann Med Exp Biol Fenn. 1972; 50(3): 99-162.

51. Kortev AI, Donthov GI, Lyascheva AP. Bioelements and a human pathology. Sverdlovsk, Russia: Middle-Ural publishing-house; 1972.

52. Soman SD Joseph KT, Raut SJ, et al. Studies of major and trace element content in human tissues. Health Phys. 1970; 19(5): 641-656.

53. Teraoka H. Distribution of 24 elements in the internal organs of normal males and the metallic workers in Japan. Arch Environ Health. 1981; 36(4): 155-165.

54. Boulyga SF, Becker JS, Malenchenko AF, Dietze H-J. Application of ICP-MS for multielement analysis in small sample amounts of pathological thyroid tissue. Microchimica Acta. 2000; 134(3-4): 215-222.

55. Jundt FC, Purser KH, Kubo H, Schenk EA. Proton-induced X-ray analysis of trace elements in tissue sections. J Histochem Cytochem. 1974; 22(1): 1-6.

56. Maeda K, Yokode Y, Sasa Y, Kusuyama H, Uda M.Multielemental analysis of human thyroid glands using particle induced X-ray emission (PIXE). Nucl Instrum Methods Phys Res B. 1987; 22(1-3): 188-190.

57. Nishida M, Sakurai H, Tezuka U,et al. Alterations in manganese and iodide contents in human thyroid tumors; a correlation between the contents of essential trace elements and the states of malignancy. Clinica Chimica Acta. 1990; 187(2): 181-187.

58. Tardos TG, Maisey MN, Ng Tang Fui SC, Turner PC. The iodine concentration in binign and malignant thyroid nodules measured by X-Ray fluorescence. Brit J Radiol. 1981; 54: 626-629.

59. Al-Sayer H, Mathew TC, Asfar S, et al. Serum changes in trace elements during thyroid cancers. Mol Cell Biochem 2004; 260(1): 1-5.

60. Kaya G, Avci H, Akdeniz I, Yaman M. Determination of Trace and Minor Metals in Benign and Malign Human Thyroid Tissues. Asian J Chem.2009; 21(7): 5718-5726.

61. Katoh Y, Sato T, Yamamoto Y. Determination of multielement concentrations in normal human organs from the Japanese. Biol Trace Elem Res.2002; 90(1-3): 57-70.

62. Schroeder HA, Tipton IH, Nason AP. Trace metals in man: strontium and barium. J Chron Dis. 1972; 25(9): 491-517.

63. Zaichick V. Sampling, sample storage and preparation of biomaterials for INAA in clinical medicine, occupational and environmental health. In: Harmonization of Health-Related Environmental Measurements Using Nuclear and Isotopic Techniques. Vienna: IAEA; 1997: 123-33.

64. Zaichick V, Zaichick S. A search for losses of chemical elements during freeze-drying of biological materials. J Radioanal Nucl Chem. 1997; 218(2): 249-253.

65. Zaichick V. Losses of chemical elements in biological samples under the dry aching process. Trace Elem Med. 2004; 5(3):17-22.

66. Pavelka S. Radiometric determination of thyrotoxic effects of some xenobiotics. Rad Applic. 2016; 1(2): 155-158.

67. Maschkovsky MD. The sedatives. In:The Medicaments. 15th Ed. Moscow: Novaya Volna; 2005: 72-86.

68. Zaichick V. X-ray fluorescence analysis of bromine for the estimation of extracellular water. J Appl Radiat Isot. 1998; 49(12): 1165-1169.

69. Zaichick V, Zaichick S. The silver, cobalt, chromium, iron, mercury, rubidium, antimony, selenium and zinc contents in human bone affected by Ewing's sarcoma. J Cancer Tumor Int. 2015; 2(1): 21-31.

70. Zaichick S, Zaichick V. The content of silver, cobalt, chromium, iron, mercury, rubidium, antimony, selenium, and zinc in osteogenic sarcoma. J Cancer Ther. 2015;6(6): 493-503. 
71. Zaichick V, Zaichick S. The silver, cobalt, chromium, iron, mercury, rubidium, antimony, selenium, and zinc contents in human bone affected by chondrosarcoma. J Hematology Oncol Res. 2015; 1(4): 25-36.

72. Zaichick V, Zaichick S. The content of silver, cobalt, chromium, iron, mercury, rubidium, antimony, selenium, and zinc in malignant giant cell tumor of bone. Arch Cancer Res 2015;3(4:38): 1-9.

73. Zaichick V, Zaichick S. Distinguishing malignant from benign prostate using content of 17 chemical elements in prostatic tissue. Integr Cancer Sci Therap.2016; 3(5): 579-587.

74. Zaichick V, Zaichick S. Trace element contents in adenocarcinoma of the human prostate gland investigated byneutron activation analysis. CancerRes Oncol. 2016; 1(1): 1-10.

75. Zaichick V, Zaichick S. Prostatic tissue levels of 43 trace elements in patients with prostate adenocarcinoma. Cancer Clin Oncol. 2016; 5(1): 79-94.

76. Moncayo R, Moncayo H. Applying a systems approach to thyroid physiology: Looking at the whole with a mitochondrial perspective instead of judging single TSH values or why we should know more about mitochondria to understand metabolism. BBA Clin. 2017; 7: 127-140.

77. Chandra A.K. Effects of magnesium on cytomorphology and enzyme activities in thyroid of rats. Indian J Exp Biol. 2014; 52: 787-92.

78. Jiménez A. Changes in bioavailability and tissue distribution of selenium caused by magnesium deficiency in rats. JAm Coll Nutr. 1997; 16: 175-180.

79. Durlach J, Bara M, Guiet-Bara A, Collery P. Relationship between magnesium, cancer and carcinogenic or anticancer metals. Anticancer Res. 1986; 6: 1353-1361.

80. Mulay IL, Roy R, Knox BE, Suhr NH, Delaney WE. Trace-metal analysis of cancerous and noncancerous human tissues. J Natl Cancer Inst. 1971; 47:1-13.

81. Anghileri LJ, Miller ES, Robinette J, Prasad KN, Lagerborg VA. Calcium metabolism in tumors. II. Calcium, magnesium and phosphorus in human and animal tumors. Oncol. 1971; 25: 193-209.

82. Digiesi V, Bandinelli R, Bisceglie P, Santoro E. Magnesium in tumoral tissues, in the muscle and serum of subjects suffering from neoplasia. Biochem Med. 1983; 29: 360-363.

83. Szmeja Z, Koenczewska H. Red blood cell, serum and tissue magnesium levels in subjects with laryngeal carcinoma. J Otorhinolaryngol Relat Spec. 1983; 45: 102-107.

84. Ranade SS, Panday VK. Major metals in human cancer: calcium, magnesium, sodium and potassium. Sci Total Environ. 1985; 41: 79-89.

85. Taylor JS, Vigneron DB, Murphy-Boesch J, et al. Free magnesium levels in normal human brain and brain tumors: 31P chemical-shift imaging measurements at 1.5 T. Proc Natl Acad Sci USA. 1991; 88: 6810-6814.

86. Collery P, Anghileri LJ, Coudoux P, Durlach J. Magnesium and cancer: Clinical data. Magnesium Bull. 1981; 3: 11-20.

87. Wolf FI, Cittadini ARM, Maier AM. Magnesium and tumors: Ally or foe? Cancer Treatment Rev. 2009; 35(4): 378-382.

88. Trump BF, Berezesky IK, Phelps PC. Sodium and calcium regulation and the role of the cytoskeleton in the pathogenesis of disease: a review and hypothesis. Scan Electron Microsc. 1981; (Pt2):434-454.

89. Ranade SS, Panday VK. Major metals in human cancer: calcium, magnesium, sodium and potassium. Sci Total Environ. 1985; 41(1): 79-89.

90. Romeu A, Arola L, Alemany M. Essential metals in tissues and tumor of inbred C57BL/6 mice during the infective cycle of Lewis lung carcinoma. Cancer Biochem Biophys. 1986; 9(1): 53-66.

91. Ouwerkerk R, Jacobs MA, Macura KJ, et al. Elevated tissue sodium concentration in malignant breast lesions detected with non-invasive 23Na MRI. Breast Cancer Res Treat. 2007; 106(2): 151-160. 